\title{
Blue is (NOT) THE WARMEST Colour: Contradictions of Grieving in Joan Didion's BLUE NIGHTS
}

\begin{abstract}
Six years after publishing her acclaimed memoir of spousal loss, i.e. The Year of Magical Thinking (2005), in which she memorably wrote about the death of her husband John Gregory Dunne, Joan Didion returned to the field of (auto)thanatography. This time Didion produced a devastating account of the death of her daughter Quintana, who died at the age of thirty-nine, only twenty months after John. However, Blue Nights (2011) turned out not to be a conventional memoir of loss which would easily succumb to the laws of the genre. On the contrary, instead of exclusively paying tribute to the memory (and life) of her daughter, or trying to testify to the process of grieving, Quintana's demise invited Didion to turn her attention to her own self and address such issues as ageing and loneliness, parenthood, displacement, as well as her own impending death. Consequently, Didion wrote the most paradigmatic form of autobiography, which, as Nancy K. Miller famously stated, is an act of "writing against death twice: the other's and one's own" (Miller 1994: 12). The aim of this paper is to discuss Blue Nights as a narrative of grief and/or death. The conceptual framework of this analysis will be provided by an inquiry into the (titular) colour blue and its cultural contexts.
\end{abstract}

\section{Key words}

Joan Didion; memoir; autothanatography; blue 
A friend says he thinks of gender as a color. Gender does share with color a certain ontological indeterminacy: it isn't quite right to say that an object is a color, nor that the object has a color. Context also changes it: all cats are grey, etc. Nor is color voluntary, precisely. But none of these formulations means that the object in question is colorless. (Nelson 2016: 18)

What is blue? The sky is blue

Where the clouds float through. (Rossetti 1872: 51)

"Do you not see its blue waves above us?"

He looked up, and the blue stream was flowing gently over his head.

"Where are we, dear Matilda?"

"With our fathers".

"Shall we remain together?"

"Forever", she replied. (Novalis 1842: 136)

\section{Chromophobes and Chromophiliacs}

"And so I fell in love with the color - in this case, the color blue - as if falling under a spell, a spell I fought to stay under and get out from under, in turns" (Nelson 2009: 1) - thus Maggie Nelson opens her book long essay on the colour blue. In line with Michel Pastoureau's claim that any history of colour is essentially an "interdisciplinary" field of research, Nelson's study, tellingly titled Bluets, ${ }^{1}$ is a multifaceted and versatile inquiry into the colour understood as a "complex cultural construct" that requires - for the purpose of its felicitous investigation - that all cultural "documents" related to it be thoroughly examined (Pastoureau 2001: 7-10). With her book Nelson joins a panoply of artists, writers and philosophers who, over the centuries, have shown some extraordinary interest in the colour blue; those "chromophobes" and "chromophiliacs" 2 who, to paraphrase the words of Novalis, have been "haunted" 3 by it: the likes of Simone Martini, Ambrogio Lorenzetti and Giotto; ${ }^{4}$ Pablo Picasso and Claude Monet; ${ }^{5}$ Ludwig Wittgenstein, William H. Gass, Marguerite Duras and Tejī Grover. ${ }^{6}$ Perhaps the most widely known "theoretician" of blue is Johann Wolfgang von Goethe who famously wrote about the very colour in his Zur Farbenlehre (Theory of Colours) of 1810, stating that "we love to contemplate blue, not because it advances to us, but because it draws us after it" (311). Goethe was not the first ${ }^{7}$ to acknowledge the self-contradictory nature of blue but certainly one of the most prominent voices emphasising blue's dualism: not only the colour of heavenly light which for centuries was almost synonymous with gold (Pastoureau 2001: 49-56), but also the colour which "brings a principle of darkness with it" and claims a symbolic and material affinity with black (Goethe 1840:310). According to Goethe, blue is also capable of powerfully "giv[ing] us an impression of cold" and "remind[ing] us of 
shade"; the objects seen through a blue glass are "gloomy and melancholy" while blue rooms appear "empty and cold", the writer observes (311). The acknowledgement of blue's paradoxical character, its inherent "contradiction between excitement and repose" (311) has been echoed by other sophists of blue: from the father of Henry of Ofterdingen in Novalis's novel ${ }^{8}$ to the writing of Maggie Nelson, as exemplified by the opening line of the present essay. ${ }^{9}$

Joan Didion is among the more recent contributors to the on-going investigation of blue. Her 2011 memoir Blue Nights, dedicated to Didion's daughter Quintana, who died on 26 August 2005, twenty months after her father John Gregory Dunne, ${ }^{10}$ can certainly be seen as another piece of writing that problematises blue's antithetical nature; as in the passage that opens the whole volume:

In certain latitudes there comes a span of time approaching and following the summer solstice, some weeks in all, when the twilights turn long and blue. [...] You notice it first as April ends and May begins, a change in the season, not exactly a warning - in fact not at all a warning - yet suddenly summer seems near, a possibility, even a promise. You pass a window, you walk to Central Park, you find yourself swimming in the color blue: the actual light is blue, and over the course of an hour or so this blue deepens, becomes more intense even as it darkens and fades, approximately finally the blue of the glass on a clear day at Chartres, or that of the Cerenkov radiation thrown off by the fuel rods in the pools of nuclear reactors. The French called this time of the day "l'heure bleue". To the English it was "the glooming". [...] During the blue nights you think the end of the day will never come. As the blue nights draw to a close (and they will, and they do) you experience an actual chill, an apprehension of illness, at the moment you first notice: the blue light is going, the days are already shortening, the summer is gone. This book is called "Blue Nights" because at the time I began it I found my mind turning increasingly to illness, to the end of promise, the dwindling of the days, the inevitability of the fading, the dying of the brightness. Blue nights are the opposite of the dying of the brightness, but they are also its warning. (Didion 2011: 3-4)

The quoted piece ostensibly salutes a number of blue's features that have been identified by Goethe and other "readers" of the colour: it is synonymous with "light", "possibility", and "promise", but also with "chill", "apprehension", and "illness"; it is a warrant of life and a presentiment of death; it is the colour of the spirit (Chartres's glass) and of the matter (Cerenkov radiation).

The paradox of blue, its dual nature, unambiguously provides a central metaphor and a narrative frame for Didion's story - a piece inevitably concerned with both death and life, darkness and light. Similarly to the speaker of Stéphane Mallarmé's poem "L'azur", the narrator of Blue Nights is "haunted"11 by blue, which she sees not only when the sun stands still ${ }^{12}$ but which also subtly features in a number of episodes throughout the book: when Didion finds Quintana's 
"navy-blue gym shorts" and "blue-and-white pinafore" (45), or recalls "blueand-white" printed curtains of the intensive care units (15), The Broken Man's ${ }^{13}$ "blue work shirt" (51) and "blue sharks" near the Zuma Beach where her daughter trained as a junior lifeguard (88). Didion's titular reference to the colour blue also foreshadows a series of contrastive tropes which are intensely present in her memoir. A contradictory nature of blue is reflected in, among others, Didion's various observations: for example, when she refers to adoption as both a "blessing" and a "chill" (58). ${ }^{14}$ Her use of pronouns characterised by abrupt changes from singular "I" to plural "We"(e.g. 61) and persons (e.g. "Had there be an instant when Tasha was afraid not to die? Had there be an instant when Quintana was afraid not to die?" [25]), as well as images which always partake in light and darkness, positivity and negativity might also be seen as a testament to the legacy of blue. A vision of the perfect house and family life in Malibu where Didion and Dunne moved in 1971 is, for example, immediately spoilt by the writer's references to the wind "blow[ing] down through the canyons and whin[ing] under the eaves and lift[ing] the roof and coat[ing] the white walls with ash"15 (27). Quintana's wedding ceremony is corrupted by a premonition of the bride's soon-to-come illness and decease: "Could you have seen, had you been walking on Amsterdam Avenue and caught side of the bridal party that day, how utterly unprepared the mother of the bride was to accept what would happen before the year 2003 had even ended? The father of the bride dead at his own dinner table? The bride herself in an induced coma, breathing only on a respirator, not expected by the doctors in the intensive care unit to live the night?" (15). Or, alternatively, Didion's own "corporeal ineptness" (175) is juxtaposed with Sophia Loren (her agemate) arriving at a publicity event: "This entirely meaningless discovery floods me with restored hope, a revived sense of the possible", Didion concludes (182). All those thematic and structural dichotomies are, as I should like to argue, an evident exemplification of Didion's indebtedness to the heritage of blue and acknowledgement of the antithetical principle that it welcomes.

Yet, what this essay wishes to explore in particular is how blue's contradictory nature influences not only thematic but also generic aspects of the narrative; how Blue Nights embraces and at the same time discards the category of the "grief memoir" and, consequently, can be recognised as a paradigmatic example of what Nancy K. Miller described as "autothanatography" (Miller 1994: 12), the "truest" of all autobiographies.

\section{Apprentices at Mourning}

Over the last two or three decades the so-called grief memoirs have become one of the most popular forms of life narratives. This fact has been testified to not only by the sheer number of its specimens written in the period but also by the arrival and proliferation of various new categories aimed to "designate narratives that focus on death" (Couser 2012: 43). Consequently, death writing has been 
labelled "bereavement memoir" (Jolly 2001: 568), "memoir on loss" and "misery memoir" (Anderson 2011: 116), "narratives of grief" and "narratives of mourning" (Smith and Watson 2010: 138), or "end-of-life memoirs" (Berman 2012: 11). Simultaneously, a set of thematic/formal characteristics that can function as markers of the genre have emerged (Smith and Watson 2010: 138-141). Firstly, its specimens appear to occupy a threshold space between intimacy and private mourning (contemplation and chronicle of personal loss) and "collective vulnerability and communal loss" (Smith and Watson 2010: 139). Such a narrative is a public form of mourning not only because it "publicises" grief of an individual, but also due to a public role that it plays. Secondly, grief memoirs are means of endurance, testaments to the life of the departed that wish to commemorate the (mostly beloved) dead and preserve their memory for posterity. Also, they most often function as books of consolation: they are guidebooks on how to deal with loss and bereavement, and how to recover from grief. In short, they are manuals of (self-)repair. Prioritisation of this therapeutic function led to an emergence of another term, namely "scriptotherapy" by Suzette Henke (1998). According to Henke, the singular objective of grief memoirs (and other types of autobiographical writing dealing with trauma) is self-healing. While commenting on this category, G. Thomas Couser trenchantly points out that "the term emphasizes the work of the narrative - its goal or aim - rather than its form" (Couser 2012: 43). Couser's comment brings one to, perhaps, the most important debate which remains at the heart of contemporary grief writing: therapeutics vs. literariness. In recent years, inundated with the products of grief memoirists, many have wondered about the role and function of death writing. In Nothing to Be Frightened Of Julian Barnes challenged the idea that writing about grief/telling one's story is an indispensable element of healing and labelled it "therapeuto-autobiograhical fallacy" (Barnes 2009: 97). In an essay entitled "Regulating Sorrow" from the collection Through the Window, he further pondered on the difficulties that grief memoirs pose for interpreters: ${ }^{16}$

In some way autobiographical accounts of grief are unfalsifiable, and therefore unreviewable by any normal criteria. The book is repetitive? So is grief. The book is obsessive? So is grief. The book is at times incoherent? So is grief. Phrases like "Friends have been wonderful inviting me to their homes" are platitudes; but grief is filled with platitudes. (Barnes 2012: 222)

Finally, the last principle that appears to apply to grief memoirs is that they are essentially anti-death writing (consequently, most literally life writing), where a dying person (or their companions) want to take charge and claim agency of their story, make meaning out of life, while the narrative itself testifies to the "revealing processes of self-understanding" (Egan 1999: 8, 200, 207). According to Susanna Egan, one of the first theoreticians of death writing, such attempts are "less concerned with mimesis, however, than with authenticating the processes of discovery and re-cognition" (Egan 1999: 7). 
Does Blue Nights, one might be tempted to ask taking into account the subject matter of the present paper, respect the above-listed "laws" of grief memoirs? Or, alternatively, true to its central metaphor of the colour blue and its principle of contradiction, does the volume remain in a labyrinthine relationship with its genre? Does it violate its laws?

First, I should like to claim, Didion's memoir is quite unorthodox in the way it addresses the subject of mourning. ${ }^{17}$ Published six years after her daughter's death, Blue Nights - despite being pervaded by the sense of loss (e.g. "I find myself thinking exclusively about Quintana. I need her with me" [150]) - is not interested in tracing or giving voice to a trajectory of grief: denial, anger, or bargaining, to name just a few of its symptoms. ${ }^{18}$ It does not provide a documentation of Didion's bereavement (as a matter of fact it does not even communicate to the volume's readers what exactly happened to Quintana). However, neither does the book testify to the fact that the writer's work of mourning has been completed; that, to use Freud's terms, "the ego" has become "free and uninhibited again" (Freud 1961: 244-245). Unlike in The Year of Magical Thinking ${ }^{19}$ Didion shows no interest in her mental condition immediately following the death of her nearest and dearest, nor wishes to achieve any kind of "satisfactory resolution" (45). In one of the very few excerpts that are ostensibly concerned with Didion's mourning, the writer says: "Five years since Gerry [Quintana's husband - author's note] and I left her in the ICU overlooking the river at New York Cornell. I can now afford to think about her. I no longer cry when I hear her name. I no longer imagine the transporter being called to take her to the morgue after we left the ICU. Yet I still need her with me" (151).

The memoir's ambivalence towards the poetics of mourning is also reflected in its vacillating attitude towards the subject of the narrative.$^{20}$ In Didion's narrative, the readers familiar with "normative" grief memoirs will not find a typical pean to the departed: notification of Quintana's achievements, an overview of her life, personal and professional successes, praise of her personal virtues. If one of the aims of grief memoirs is to commemorate the dead and to preserve them via narrative, Blue Nights contains surprisingly few laudable eulogies or commendations directed at Didion's daughter, of whom we, in fact, learn relatively little. The memoir is deliberately anti-commemorative ("I no longer want reminders of what was, what got broken, what got lost, what got wasted" [44]); more so, it is at odds with the very principle of remembering: ${ }^{21}$

Memories are not [solace]. Memories are by definition of times past, things gone. Memories are the Westlake uniforms in the closet, the faded and cracked photographs, the invitations to the weddings of the people who are no longer married, the mass cards from the funerals of the people whose faces you no longer remember. Memories are what you no longer want to remember. (64)

The writer pays some considerable attention to Quintana's childhood and her wedding day but for most of the narrative she is not the principal subject of the 
story. This position is, in fact, occupied by Didion herself. "When we talk about mortality we are talking about our children", Didion proclaims in one of the initial chapters of the book (13) and thus revels an autobiographical impulse at the heart of the story. Writing about Quintana is a means of writing about oneself.

Like the colour blue spread between two opposites, the narrative of Blue Nights fluctuates between the mother and the daughter. It may appear, especially in the second part of the volume, ${ }^{22}$ that incidents from Quinatna's life are primarily pretexts for Didion's story of self, in particular the story of Didion's growing frailty. "As the pages progressed it occurred to me that their actual subject was not children after all, at least not children per se, at least not children qua children: their actual subject was this refusal even to engage in such contemplation, this failure to confront the certainties of ageing, illness, death", Didion confesses (54). Elsewhere she further acknowledges the very subject of her memoir, which she reveals relatively late in the book: "Also notice - in notes that talk about ageing in their first few pages, notes called Blue Nights for a reason, notes called Blue Nights because at the time I began them I could think of little other than the inevitable approach of darker days - how long it took me to tell you that one salient fact, how long it took me to address the subject as it were. Ageing and its evidence remain life's most predictable events, yet they also remain matters we prefer to leave unmentioned, unexplored" (25). Consequently, one is tempted to recognise that Blue Nights is not so much about grieving for the dead child, but about one's inevitable demise - not a grief memoir but, in fact, an example of death writing, a specimen of autothanatography. The very term was coined by Nancy K. Miller in an essay entitled "Representing Others: Gender and the Subjects of Autobiography", in which she argued against "a cold-war rhetoric of autonomous selfhood" (3) and proposed a new view of male autobiographical identity. When analysing Jacques Derrida's Circonfession (an autobiographical commentary and a re-reading of Augustine's Confessions), Miller focuses on passages dedicated to illness and death of Derrida's mother and makes the following conclusion: "autobiography - identity through alterity - is also writing against death twice: the other's and one's own. Every autobiography, we might say, is also an autothanatography" (12). For Miller, "intimate and violent dialogues with living and dead others perform the bedrock of self-construction itself" (19). She also states: "One always confesses the other. [...] In order to represent himself completely, the son must represent his mother, his other, without omitting a word. It falls to the son, to recreate the dead parent through writing; to give birth to the author of one's life, and hence to authorise himself" (11). Though Didion reverses the paradigm (it is the mother that "must represent" her daughter in order to represent herself), Blue Nights can certainly be recognised as a paradigmatic "autobiography [which] is also an autothanatography" - the one that principally represents oneself through representing the other.

However, the contradictory (blue, one might say) principle at the heart of Blue Nights also problematises any unequivocal attempt to apply the category of autothanatography to it - particularly in its resistance to write against death. Though 
Didion admits to "pushing [oneself] beyond endurance" (170) and that she tells her story to "prove that [she] can", that her "frailty has not yet reached a point at which [she] can no longer tell a true story" (109). Blue Nights is not a "rage against the dying of the light" (Thomas 2003: 239) but an examination of one's process of "pass[ing] into nothingness" (Didion 2011: 132). Didion carefully documents various failures of her body: names "vanish"; reminiscences "blur" and become "mudgy" (102); "even the correct stance for telling you this, the way to describe what is happening to me, the attitude, the tone, the very words, now elude my grasp" (116). She falls. She suffers from neurological inflammation. She loses weight and cannot gain it back despite the supervision of a dietician and drinking protein shakes. She is overtaken by resignation ("I abandon the attempt to answer these questions" [107]). She falls down again and is hospitalised. She gets shingles. "Demoralisation occurs in the instant", she says of her condition (146). Instead of being an anti-death writing, Blue Nights becomes a poignant narrative about the writer's own demise and an attestation of the passage from light to darkness: an embrace of the "dying of the light".

Didion's sense of an approaching end is also conceptualised by the trope of displacement, by the narrative which by means of following an ontopological ${ }^{23}$ impulse links its subject's bios to tópos, the subject's life to a place which she inhabits. In the opening section of her book Didion insists on an antithetical relationship between the West and East coast of the United States, between California and New York City. She says: "The period of the blue nights does not occur in subtropical California, where I lived for much of the time I will be talking about here and where the end of daylight is fast and lost in the blaze of the dropping sun, but it does occur in New York, where I now live" (Didion 2011: 3). Indeed, the book's major locations are the two houses in California (first Pacific Coast Highway at the west end of Malibu and then Brentwood Park, Miami, where Didion and her family moved in 1971 and 1978 respectively) - places that represent life and happiness ${ }^{24}$ - and New York City hospitals, which stand for death and despair. Didion's current locality thus becomes synonymous not only with the loss of her family members but, most importantly, with her own falling away:

For everything there is a season. I'd miss having the seasons, people from New York like to say by way of indicating the extraordinary pride they take in not living in Southern California. In fact Southern California does have seasons (it has for example "fire season" or "the season when the fire comes", and it also has "the season when the rain comes"), but such Southern California seasons, arriving as they do so theatrically as to seem strokes of random fate, do not inexorably suggest the passage of time. Those other seasons, the ones so prized on the East Coast, do. Seasons in Southern California suggest violence, but not necessarily death. Seasons in New York the relentless dropping of the leaves, the steady darkening of the days, the blue nights themselves - suggest only death. (Didion 2011: 68-69) 
Finally, by, subtly yet directly, addressing its author's own mortality, by being death writing par excellence, Blue Nights renounces another principle of grief writing - its consolatory and therapeutic function. Diana Athill in her old age memoir Somewhere Towards the End of 2009 says: “One doesn't necessarily have to end a book about being old with a whimper, but it is impossible to end it with a bang. There are no lessons to be learnt, no discoveries to be made, no solutions to offer. I find myself left with nothing but a few random thoughts" (Athill 2009: 177). Similarly to Athill's memoir, Blue Nights does not offer "lessons", "discoveries" or "solutions" since it is not the story of survival but of vanishing. The sense of finality is most explicitly expressed by the volume's final words:

Vanish. Pass into nothingness: the Keats line that frightened her. Fade as the blue nights fade, go as the brightness goes. Go back into the blue. I myself placed her ashes in the wall. I myself saw the cathedral doors locked at six. I know what it is I am now experiencing. I know what the frailty is, I know what the fear is. The fear is not for what is lost. What is lost is already in the wall. What is lost in already behind the locked doors. The fear is for what is still to be lost. You may see nothing still to be lost. Yet there is no day in her life on which I do not see her. (188)

Tracey Daugherty, Didion's biographer, pays attention to what appears to be a grammatical (logical) mistake - a pronoun "her [life]" instead of "my" - and insists on its deliberate usage by Didion: "She equated herself with Quintana. She made mother and daughter, life and death, indistinguishable, separated not even by a sheer blue-and-white curtain. Not for the first time, Didion was both the lost child abandoned on the trail and the survivor, looking back" (Daugherty 2015: 581).

\section{"Did I believe the blue nights could last forever?"}

Towards the end of her autotanatography, Didion once again returns to the trope of "blue nights":

On the afternoon she herself died, August 26, 2005, her husband and I left the ICU overlooking the river at New York Cornell and walked through Central Park. The leaves on the trees were already losing their intensity, still weeks from dropping but ready to drop, not exactly faded but fading. At the time she entered the hospital, late in May or early in June, the blue nights had just been making their appearance. I had first noticed them not long after she was admitted to the ICU [...]. It was a period when improvement seemed possible. [...] Then one night, leaving the ICU [...], I realized: there would be no step-down unit. The light outside had already changed. The light outside was no longer blue. (157-159) 
The above-quoted passage, true to the poetics of the whole narrative, has two characters: not only the daughter that has just died but also the mother who is about to die, "still weeks from dropping but ready to drop, not exactly faded but fading" (158). For Didion, the period of blue nights is over. The sky and its light are no longer blue, both for Quinatana and for herself. "So what is their colour?", one may be tempted to ask.

In Chroma, Derek Jarman's study of colours published only a couple of months before his death, blue occupies a very special place. Jarman, perhaps the last in the series of great chromophiliacs, does not only follow Goethe in his recognition of blue's contradictory nature but, stronger than any theorist of colour before him, links the colour blue to death."Blue is darkness made visible", Jarman writes (114); "How did my friends cross the cobalt river, with what did they pay the ferryman", he asks (115) in a section of Chroma ("Into the blue") which addresses his becoming blind and slowly dying from AIDS-related diseases and which tellingly ends with the following words: "I place a delphinium, Blue, upon your grave" (124). In one of the meditations dedicated to blue, Jarman - crucially for my attempt to answer the question posed in the previous paragraph - recalls a $15^{\text {th }}$-century painting by the Dutch artist Geertgen tot Sint Jans entitled Nativity at Night. Pondering on its use of colour, Jarman notices the domineering presence of "black blue sadness" in it: "The virginal blue robe which mirrors the blue sky is swallowed by black" (103).

The colour of the sky and the light which Didion sees upon leaving the hospital where her daughter has died and which she never reveals to her readers is, I should like to conclude, the very colour identified by Jarman in Geertgen's painting: black. Blue Nights, this transgressive piece of autothanatography, is not only a narrative about one mother's loss of a child and her own demise; not only an original contribution to a multifaceted and interdisciplinary study of blue; but, most importantly, a testament to the fact that "the blue nights could [not] last forever" (17); that blue always inevitably turns to black.

\section{Notes}

$1 \quad$ "Les bluets" translate into English as "cornflowers", also known as bluebottles or bachelor's buttons. The title of Nelson's book is an undisguised allusion to (as well as travesty of) Novalis's blue flower which famously features in his unfinished novel Heinrich von Ofterdingen (1802).

2 I have borrowed the two terms from the title of one of the chapters of Pastoureau's abovementioned study, i.e. "Les prélats chromophobes et chromophiles".

3 "I long to see the blue flower. / I can't get rid of the idea, it haunts me" (Novalis 1891: 53).

$4 \quad$ E.g. The Maestà, The Equestrian Portrait of Guidoriccio da Fogliano and The Allegory of Good and Bad Government in Palazzo Pubblico in Siena, as well as the Saint Francis cycle in the Upper Church of San Francesco at Assisi.

5 Picasso's Blue Period (e.g. Melancholy Woman, Portrait of Suzanne Bloch) and Monet's Blue Water Lilies series. 
I.e. Wittgenstein's Bemerkungen über die Farben (1977), Gass's On Being Blue: A Philosophical Inquiry (1976), Duras's Les Yeux bleus, cheveux noirs (1986), Grover's Neela (1999).

In his Color and Meaning John Gage offers a detailed discussion of a number of debates on blue from Aetius of Antioch to Kurt Badt and Michel Pastoureau. He calls attention to the ancient and early medieval recognition of blue as essentially dual and boasting affinity with both darkness and light (Gage 1999: 73-76).

“'Dear father', eagerly exclaimed Henry, 'do tell me its color'. 'I cannot recollect it, though it was so fixed in my mind at the time'. 'Was it not blue?'" (Novalis 32; emphasis mine). One should note that Heinrich von Ofterdingen was completed ten years before the publication of Goethe's work on colour.

"A spell I fought to stay under and get out from under, in turns" (Nelson 2009: 1; emphasis mine).

Whose loss Didion memorably addressed in her bestselling and acclaimed The Year of Magical Thinking of 2005.

“Je suis hanté. L'Azur! l’Azur! l’Azur! l'Azur!” (Mallarmé 1986: 80).

The origin for the English word summer solstice is the Latin noun "sol" (sun) and verb "sistere" (to stand still).

A figure that populates Quintana's nightmares.

Elsewhere she says: "The world has nothing but Mornings and Nights" (133).

Not to mention "the king snakes that dropped from the rafters of the garage into the open Corvette [Didion] parked below" (27).

But others were less kind than Barnes. Infuriated by exhibitionism, cliché and melodrama in recently published Joan Didion's The Year of Magical Thinking, David Rieff's Swimming in a Sea of Death, Anne Roiphe's Epilogue, Joyce Carol Oates's A Widow's Story, Meghan O'Rourke's The Long Goodbye and Francisco Goldman's Say Her Name (all about the death of spouses or parents), Frances Stonor Saunders in the Guardian Book Review claimed, in August 2011, that it was "time to stop the outpouring the memoirs" and, in a crushing review of the above mentioned works of mourning, implored the memoirists: "don't give me grief" (Saunders 2011: 1-3).

17 This aspect has also been noted by Didion's biographer Tracy Daugherty: "When Didion's Blue Nights came out in the late fall of 2011, the publisher hailed it as 'a work of stunning frankness about losing a daughter'. It was hardly that. It was an impressionistic collage of isolated memories, slant observations, list of objects, and riffs on rhythm. Several times during the writing, Didion nearly abandoned the projects, but Lynn Nesbit, her agent, talked her out of it. The book went from being a meditation on parenting to a love song for Quintana to a lengthy complaint about ageing and mortality. It ended up as none of these, quite" (Daugherty 2015: 580).

Elizabeth Kübler-Ross's most influential On Death and Dying identifies five stages of grief: 1) denial and isolation (51-62), 2) anger (63-92), 3) bargaining (93-96), 4) depression (97122), 5) acceptance (123-146).

Which ends on a note of triumph over despair, with the image of the writer swimming with her husband at Portuguese Bend, who implores her: "You [have] to feel the swell change. You [have] to go with a change" (Didion 2005: 353).

As already mentioned, the subjects that the book addresses - apart from or, in fact, next to Quintana's death - include parenthood, adoption, migration and travelling, and ageing, to name a few.

"Memory fades, memory adjusts, memory confirms to what we think we remember" (13).

As signalled by Didion's biographer, the volume is particularly fragmentary ("impressionistic collage" [Daugherty 2015: 580]) and one can observe a gradual shift in the interest the volume takes in Quintana (who features more prominently in the opening sections) and her mother (who becomes the primary subject as the book progresses). 
23 I have borrowed the term from Jacques Derrida's Specters of Marx. According to Derrida, ontopology is "an axiomatics linking indissociably the ontological value of present-being $[o n]$ to its situation, to the stable and presentable determination of a locality, the topos of territory, native soil, city, body in general" (Derrida 2006: 102-103). See Daugherty (2015: 297-319, 397-416).

\section{References}

Anderson, Linda (2011) Autobiography. London and New York: Routledge.

Athill, Diana (2009) Somewhere Towards the End: A Memoir. New York and London: W.W. Norton \& Company.

Barnes, Julian (2009) Nothing to Be Frightened Of. London: Vintage.

Barnes, Julian (2012) Through the Window: Seventeen Essays (and one short story). London: Vintage.

Berman, Jeffrey (2010) Companionship in Grief: Love and Loss in the Memoirs of C. S. Lewis, John Bayley, Donald Hall, Joan Didion, and Calvin Trillin. Amherst and Boston: University of Massachusetts Press.

Daugherty, Tracy (2015) The Last Love Song: A Biography of Joan Didion. New York: St Martin's Press.

Couser, G. Thomas (2012) Memoir: An Introduction. Oxford: Oxford University Press.

Derrida, Jacques (1980) 'The law of genre'. Trans. A. Ronell. Glyph 7, 202-229.

Derrida, Jacques (2006) Specters of Marx. Trans. Peggy Kamuf. New York and London: Routledge.

Didion, Joan (2005) The Year of Magical Thinking. New York: Random House.

Didion, Joan (2011) Blue Nights. London: Fourth Estate.

Egan, Susanna (1999) Mirror Talk: Genres of Crisis in Contemporary Autobiography. Chapel Hill and London: The University of North Carolina Press.

Freud, Sigmund (1961) 'Mourning and melancholia'. In: J. Strachey (trans. and ed.) The Standard Edition of the Complete Psychological Works of Sigmund Freud. Vol. XIV (1914-1916). London: The Hogarth Press, 243-258.

Gage, John (1999) Color and Meaning: Art, Science, and Symbolism. Berkeley and Los Angeles: University of California Press.

Goethe, Johann Wolfgang von (1840) Theory of Colours. Trans. Charles Lock Eastlake. London: John Murray.

Henke, Suzette (1998) Shattered Subjects: Trauma and Testimony in Women's Life-Writing. New York: St. Martin's Press.

Jarman, Derek (1995) Chroma. Woodstock, New York: The Overlook Press.

Jolly, Margaretta (ed) (2001). Encyclopedia of Life Writing: Autobiographical and Biographical Forms. London and Chicago: Fitzroy Dearborn Publishers.

Kübler-Ross, Elizabeth (2003) On Death and Dying. New York: Scribner.

Mallarmé, Stéphane (1986) Poésies. Paris: Imprimerie nationale.

Miller, Nancy K. (1994) "Representing others: Gender and subjects of autobiography". Differences: A Journal of Feminist Cultural Studies 6(1), 1-25.

Nelson, Maggie (2009) Bluets. Seattle: Wave Books.

Nelson, Maggie (2016) The Argonauts. London: Melville House.

Novalis (von Hardenberg, Friedrich) (1842) Henry of Ofterdingen: A Romance. Cambridge: John Owen.

Novalis (von Hardenberg, Friedrich) (1891) Novalis: His Life, Thoughts, and Works. Chicago: A.C. McClurg.

Pastoureau, Michel (2001) Blue: The History of a Color. Princeton: Princeton University Press.

Rossetti, Christina G. (1872) Sing-song: A Nursery Rhyme Book. London: George Routledge and Sons. 
Saunders, Frances Stonor (2011) 'Don't give me grief'. The Guardian Book Review 20.08, 1-3.

Smith, Sidonie and Julia Watson (2010) Reading Autobiography: A Guide for Interpreting Life Narratives. Minneapolis and London: University of Minnesota Press.

Thomas, Dylan (2003) The Poems of Dylan Thomas. Daniel Jones (ed.). New York: New Directions.

RoBert KUSEK is an Assistant Professor in the Department of Comparative Studies in Literature and Culture at the Institute of English Studies of the Jagiellonian University in Krakow, Poland. His research interests include the oeuvre of J.M. Coetzee, contemporary novel in English, as well as comparative approach to literary studies and life writing genres (memoirs and biofiction in particular). He is the author of two monographs and 40 academic papers published in books and academic journals, as well as co-editor of nine volumes of articles.

Address: Instytut Filologii Angielskiej, Uniwersytet Jagielloński, al. Mickiewicza 9A, 31-120 Krakow, Poland [email: robertkusek@gmail.com] 
